\title{
Effects of Sequence Variations in Innate Immune Response Genes on Infectious Outcome in Trauma Patients: A Comprehensive Review
}

\author{
Sequence variations in trauma patients
}

\author{
Maarten W.G.A. Bronkhorst, MD FEBS FRCS ${ }^{1}$, Peter Patka, MD PhD², \\ Esther M.M. Van Lieshout, MSc $\mathrm{PhD}^{1}$
}

\footnotetext{
${ }^{1}$ Trauma Research Unit Department of Surgery, Erasmus MC,

University Medical Center Rotterdam, Rotterdam, The Netherlands

${ }^{2}$ Department of Emergency Medicine, Erasmus MC,

University Medical Center Rotterdam, Rotterdam, The Netherlands
}

\section{Address for correspondence:}

Esther M.M. Van Lieshout, MSc PhD

Erasmus MC, University Medical Center Rotterdam

Trauma Research Unit / Department of Surgery

P.O. Box 2040

3000 CA Rotterdam, The Netherlands

Phone : $\quad+31.10 .7031050$

Fax: $\quad+31.10 .7032396$

E-mail: $\quad$ e.vanlieshout@erasmusmc.nl

The authors declare that they have no conflict of interest 


\section{ABSTRACT}

Objective: Infectious complications, sepsis and multiple organ dysfunction syndrome (MODS) remain important causes for morbidity and mortality in patients who survive the initial trauma. Increasing evidence suggests that genetic variants, particularly Single Nucleotide Polymorphisms (SNPs), are critical determinants for interindividual differences in both inflammatory responses and clinical outcome in sepsis patients. Although the effect of SNPs on sepsis and MODS has been studied in many populations and diseases this review aimed to summarize the current knowledge on the effect of SNPs on infectious complication specifically in trauma patients.

Methods: review of available literature in PubMed database.

Results: The following genes have been studied in populations of trauma patients: CD14, HMGB1, IFNG, IL1A,IL1B,IL1RN,IL4,IL6,IL8,IL10,IL17F,IL18, MBL2, MASP2, FCN2, TLR1, TLR2, TLR4, TLR9, TNF, LTA, GR, MYLK, NLRP3, PRDX6, RAGE, HSPA1B, HSPAIL, HSP90, SERPINE1, IRAK1, IRAK3, VEGFA, LY96, ANGPT2, LBP, MicroRNA and mtDNA. In this review we discuss the genes of the Pattern Recognition Receptors (PRR), Signal Transducing Adaptor Proteins (STAP) and Inflammatory Cytokines of the innate immune system.

Conclusions: A number of genetic variations have so far been studied in cohorts of trauma patients. Studies are often unique and numbers sometimes small. No definitive conclusions can be reached at this time about the influence of specific sequence variations on outcome in trauma patients. 


\section{KEYWORDS}

Injury

Sepsis

Multiple Organ Dysfunction Score

Inflammatory response

Single Nucleotide Polymorphism 


\section{INTRODUCTION}

Trauma is a major public health problem worldwide, ranking as the fourth leading cause of death. In 2010, there were 5.1 million deaths from injuries and the total number of deaths from injuries was greater than the number of deaths from HIV/AIDS, tuberculosis and malaria combined (3.8 million) $(1,2)$. Infectious complications, sepsis and multiple organ dysfunction syndrome (MODS) remain important causes for morbidity and mortality in patients who survive the initial trauma (3). Although the rate of MODS in trauma patients has diminished over the last decade, MODS-related mortality, intensive care unit stay, and mechanical ventilation duration have not changed significantly $(4,5)$. These complications increase the burden of cost to society.

The primary inflammatory insult determines the magnitude of systemic inflammation and subsequent immune exhaustion, which makes patients prone for septic complications. Both a proinflammatory and anti-inflammatory response appear to coexist in trauma patients, possibly leading to both additional tissue damage by the immune system as well as increased susceptibility for subsequent infections (6). The development of the systemic inflammatory response (SIRS) with liberation of proinflammatory cytokines is recognized as a part of the physiologic response to trauma. Tissue injury following trauma results in depressed cellmediated immunity (especially T-cell) leading to an increased risk of infectious complications (7). Cytokine production varies between individuals, due to genetic background and certain allelic variants of cytokine genes; in particular, single nucleotide polymorphisms (SNPs) in coding regions of cytokine genes are associated with higher or lower cytokine production. Polymorphism may be considered as an important genetic risk factor for susceptibility to posttraumatic sepsis and a potential target for immunotherapy. Increasing evidence suggests that genetic variants, particularly SNPs, are critical determinants for interindividual differences in both inflammatory responses and clinical outcome in sepsis patients (8). Although the effect 
of SNPs on sepsis and MODS has been studied in many populations and diseases this review aims to summarize the current knowledge on SNPs in genes of the innate immune system in trauma patients only.

A literature search was performed in PubMed by using "genetic variation", "trauma", and "innate immunity" and synonyms as search string. The search was finalized by crosschecking references. Studies describing the effect of SNPs in innate immune response genes on infectious complications in trauma patients were included. An overview of the SNPs included is shown in Supplemental Table S1.

\section{Pattern Recognition Receptors and Complexes}

\subsection{Toll-Like Receptors and associated genes}

\section{Toll-Like Receptor 1 (TLR1)}

Three SNPs in TLR1 were studied in trauma patients (Table 1) (9). The TLR1 -7202G allele (rs5743551) and the TLR1 742AG(p.Asn248Ser) (rs4833095) were associated with increased risk of mortality in sepsis and Gram-positive sepsis, respectively.

\section{Toll-Like Receptor 2 (TLR2)}

Five SNP in TLR2 have been studied in a trauma population (Table 1).

The TLR2 19216T>C (rs3804099) CC genotype conferred a significantly higher risk of developing sepsis and higher MOD scores than those with a TT or TC genotype (10).

The TLR2 p.R753Q SNP was studied by two authors $(11,12)$. McDaniel et al. found the AG genotype significantly more often in septic patients $(62,5 \%)$ than in aseptic patients $(25 \%)$ in African-American patients (not so in whites) (12). Bronkhorst et al. found no association with sepsis or mortality in a mixed ethnic cohort of 219 trauma patients (11). 
For the TLR2 -16934T>A the TA genotype increased the risk of a Gram-positive infection and SIRS in a trauma population by (11) .

\section{Toll-Like Receptor 4 (TLR4)}

SNPs in TLR4 have been studied in trauma patients (11-15) and in burns patients (16-19) (Table 1). In trauma patients multiple SNPs in TLR4 have been studied making comparison difficult (11-15).

The TLR4 896A>G (rs 4986790) was studied in four cohorts of burns patients. Three studies that used the same growing cohort used sepsis as endpoint $(16,17,19)$ and two studies used mortality as endpoint $(18,19)$ The $T L R 4896 \mathrm{~A}>\mathrm{G}$ was significantly associated with an increased risk for severe sepsis $(16,17)$. Shalhub could not confirm this (19). Moreover, no association with mortality was found $(18,19)$. Carriage of the TLR4 $896 \mathrm{G}$ allele was associated with a decreased risk of complicated sepsis in trauma (15). The cosegregating TLR4 p.D299G and TLR4 p.T399I were studied in trauma patients by two authors $(11,12)$, both of whom were not able to demonstrate an association between genotype and infection or outcome of sepsis.Chen et al. studied the clinical relevance of five single nucleotide polymorphisms in TLR4 $(-2381 \mathrm{~A}>\mathrm{G},-2242 \mathrm{~T}>\mathrm{C},-1892 \mathrm{G}>\mathrm{A},-1837 \mathrm{~A}>\mathrm{G}$, and $-1418 \mathrm{~T}>\mathrm{C})$ in patients with major trauma (13). Only TLR4 $-2242 \mathrm{~T}>\mathrm{C}$ polymorphismhigher sepsis morbidity rates and multiple organ dysfunction scores were found. Duan et al. prospectively studied the TLR4 11367G>C polymorphism in patients with major trauma (14). Patients with the C variant allele had significantly lower sepsis morbidity than those homozygous for the $\mathrm{G}$ allele. In addition, MOD scores in the patients with trauma who carry the $\mathrm{C}$ allele were also significantly lower than those in the patients carrying the $\mathrm{G}$ allele. 


\section{Toll-Like Receptor 9 (TLR9)}

Several SNPs in TLR9 have been studied in trauma patients by two authors (Table 1) $(11,20)$.

Chen et al. studied the effect of five polymorphisms in TLR9 in 557 consecutive Han Chinese patients with severe multiple blunt trauma injuries (20). Median ISS was 25 and $37.9 \%$ of patients developed sepsis. The $\operatorname{rs} 187084(-1486 \mathrm{~A}>\mathrm{G}), \mathrm{rs} 352140(2848 \mathrm{C}>\mathrm{T})$ and rs352162 (6577T $>$ C) SNPs were significantly associated with TLR9-mediated TNF- $\alpha$ production. Patients with a minor allele of the rs187084, rs352139 or rs352162 polymorphism had a higher sepsis morbidity rate. Of these three SNPs, only the rs352162 polymorphism was significantly associated with MOD score, showing a recessive effect.

Bronkhorst et al. studied TLR9 (-1486T $>$ C and $-1237 \mathrm{~T}>\mathrm{C})$ in a cohort of 219 severely injured patients and found $-1486 \mathrm{~T}>\mathrm{C}$ to cause a trend toward reduced prevalence of grampositive bacteria and fungi for this SNP $(\mathrm{p}=0.060)$, but no significant association with SIRS, sepsis, or septic shock (11).

\section{Cluster of Differentiation 14 (CD14)}

The effects of $C D 14-159 \mathrm{C}>\mathrm{T}$ promoter SNP were studied in burns patients $(16-19,21-23)$ and in severely injured trauma patients $(11,24-26)$ in Chinese $(22-24,26)$ and mixed ethnic populations (Table 1) $(11,16-19,21,25)$. Comparison of results is complicated by the fact that different outcome parameters were used, including wound cultures, SIRS, sepsis, severe sepsis, MODS and mortality. Sepsis and MODS occurred more frequently in both burns and trauma patients with variant genotype in some reports $(17,22-24,26)$ but was not influenced by genotype in other reports $(11,16,19,25)$. Remarkably, in some studies sepsis was associated with the $\mathrm{C}$-allele whereas in other studies sepsis was associated with the $\mathrm{T}$ allele.(17). (22). One can only speculate about the origin of this contrast which may be explained by differences in ethnicity of the study population. Mortality risk was increased by CD14 -159C variant genotype in burns patients $(18,21)$ but this effect was not found in another study (19). 
Differences in total body surface area (TBSA) of burns as well as ethnic demographic baseline characteristics may contribute to these opposing findings.

The effects of $C D 14-1145 \mathrm{G}>\mathrm{A}$ in trauma patients were studied in Chinese trauma patients $(24,26)$. In both studies, with a total of 211 trauma patients, the $-1145 \mathrm{G}$ allele conferred an increased risk of sepsis and MODS.

\section{Myeloid differentiation-2/ Lymphocyte antigen 96 (LY96)}

Zeng et al. studied 726 unrelated Han Chinese patients with major trauma for MD2 (27). A total of 37 SNPs were identified in MD2. Thirty five of them constructed three haplotype blocks. Sepsis developed in around $40 \%$ of patients. Only the rs11465996 was shown to be significantly associated with the risk of development of sepsis and MODS in major trauma patients. Patients carrying th variant $\mathrm{G}$ allele revealed significantly higher sepsis morbidity rate and MOD scores.

$\mathrm{Gu}$ et al. studied MD2 $-1625 \mathrm{C}>\mathrm{G}$ in 105 severely injured patients of whom $40 \%$ developed sepsis (28). The MODS scores in trauma patients carrying G allele at position -1625 were significantly higher than those carrying $\mathrm{C}$ allele. Moreover, trauma patients carrying $\mathrm{G}$ allele appeared to have higher risk of sepsis compared to those carrying $\mathrm{C}$ allele. Sepsis morbidity was significantly different between subject with $\mathrm{C}$ and $\mathrm{G}$ alleles.

\section{Lipopolysaccharide Binding Protein (LBP)}

Zeng et al. used haplotype tagging to study SNPs in $L B P$ in two independent cohorts of major trauma patients recruited from southwest and eastern China (29). Of the nine known SNPs in LBP only the rs2232618 (p.F436L) was significantly associated with higher susceptibility to sepsis and MOD. Patients carrying the variant $\mathrm{C}$ allele revealed significantly higher sepsis morbidity rate and MOD scores when compared to patients carrying the T allele. 


\subsection{Lectin Pathway Proteins}

\section{Mannose-Binding Lectin (MBL2)}

Heterozygosity for the variants in exon $1(\mathrm{~A} / 0)$ conferred an increased risk of wound colonization and infection in severely injured patients (30). This had previously only been demonstrated in a murine model of burns (31). Also, the YX promoter genotype increased the risk of fungal colonization and infection in trauma patients (30).

\section{MBL-Associated Serine-Protease 2 (MASP2)}

MASP2 p.Y371D DD homozygosity increased the risk of SIRS and septic shock in trauma patients significantly (30). Moreover, a trend was noted for an increased risk of Gram-positive infections in patients with DD genotype. For the MASP2 p.D120G genotype polymorphism no statistically significant differences were found for all endpoints although, strikingly, fungi, positive blood cultures and septic shock were only found in DD patients $(22.2 \%, 15.5 \%$, and $17.9 \%$, respectively). Another striking, yet non-significant, finding was that only $8.3 \%$ of DG patients developed sepsis versus $37.7 \%$ in DD patients $(\mathrm{p}=0.060)$.

\section{Ficolin 2 (FCN2)}

The homozygous FCN2 p.A258S AS genotype increased the risk of developing septic shock in trauma patients (30). Also, wound colonization and infection risks were significantly increased. A trend was noted for Gram-negative infections.

No significant associations between the FCN2 p.T236M genotype and infectious events were found. Positive blood cultures developed in $25.0 \%$ of patients with a variant $\mathrm{MM}$ genotype, versus only $11.3 \%$ of patients with the common TT genotype but this difference was not statistically significant in a multivariate model. 


\subsection{Other Receptors}

\section{Receptor for Advanced Glycation Endproducts (RAGE)}

A total of 728 unrelated patients with major trauma was studied by Zeng et al. and genotyped for $R A G E$ (32). Sepsis occurred in around $40 \%$ of patients with median time between trauma to sepsis being 6 days. From different genetic variants selected in this study, only the RAGE 429T $>C$ (rs1800625) was shown to be significantly associated with the risk of development of sepsis and MODS in major trauma patients. The patients carrying the variant $\mathrm{C}$ allele revealed a significantly lower sepsis morbidity rate and MOD scores, when compared with those carrying the $\mathrm{T}$ allele. Moreover, in vitro LPS-induced TNF- $\alpha$ production was significantly lower in patients with the variant $\mathrm{C}$ allele than in those with wild $\mathrm{T}$ allele.

\section{NOD-like Receptor Family, Pyrin Domain Containing 3 (NLRP3)}

Zhang studied six SNPs in the NLRP3 gene of 718 Chinese patients with major blunt trauma with a mean ISS of 22.5 (33). $40 \%$ of patients developed sepsis with a mean time to sepsis of 7 days. The NLRP3 -1017G>A polymorphism (rs2027432), although it was found in only three patients with AA variant homozygotes in this study cohort, was significantly associated with higher risk of MODS. In addition, the NLRP3 5134A>G (rs12048215) polymorphism was significantly associated with a lower sepsis morbidity rate, showing $26.4 \%$ in GG versus $44 \%$ in AA. Data from multiple logistic regression analyses further indicated that the patients with the rs12048215 polymorphism had a lower risk of developing sepsis after adjusting for possible confounders. The rs2027432 polymorphism was significantly associated with higher IL-1 $\beta$ levels. 


\section{Glucocorticoid Receptor $(G R)$}

Duan et al. studied a cohort of 95 severe trauma patients with a mean ISS of 27 (34). It appeared that the BclI mutation in the GR gene was not associated with posttraumatic sepsis or organ dysfunction.

\section{Signal Transducing Adaptor Proteins}

\section{Interleukin-1 Receptor-Associated Kinase 1 (IRAK1)}

Sperry et al. studied a cohort of 321 patients with a median ISS of 16 for the T>C substitution (rs1059703) at position 1595 in exon 12 of IRAKI which results in a non-synonymous mutation (p.L532S) (35). They found this SNP to be a very strong independent predictor of post-trauma multiple organ failure and mortality

\section{Interleukin-1 Receptor-Associated Kinase 3 (IRAK3)}

Meyer et al. genotyped 474 patients with acute lung injury (ALI) from a prospective critically ill trauma patients cohort study for 25 candidate genes using the IBC chip (36). The incidence of ALI their cohort was $30 \%$. IRAK3 was found to be associated with ALI in patients from African descent.

\section{Inflammatory Cytokines}

\subsection{Interleukins}

Interleukin-I (ILIA, ILIB, ILIRN) 


\section{ILIA}

In a cohort of 308 Han Chinese trauma patients with ISS > 16 the IL1A -889C>T TT genotype had the highest risk of sepsis and produced the lowest serum levels of Il-1 $\alpha$ (Table 1) (37).

\section{ILIB}

Carrying an ILIB-Taq-1 3953C>T CT genotype in combination with the IL10 $-592 \mathrm{~A}>\mathrm{C}$ AC genotype predisposed to acute respiratory failure in Caucasian trauma patients $(\mathrm{N}=216$; ISS $>16)(\mathrm{p}=0.003)($ Table 1) $(38)$.

The $I L 1 B-1470 \mathrm{G}>\mathrm{C}$ was studied in two overlapping cohorts of severely injured Han Chinese patients from the same hospital $(37,39)$. Chinese trauma patients carrying the major 1470G allele were more likely to develop sepsis than those with the minor $-1470 \mathrm{C}$ allele in both studies.

The $I L 1 B-511 T>C$ (rs16944) was studied in the previously overlapping cohorts of 238 and 308 Han Chinese patients with severe trauma (37, 39). The CC genotype conferred a statistically significant increase in the risk of sepsis. In a Caucasian cohort of 119 multiple trauma patients $I L 1 B-511 \mathrm{~T}>\mathrm{C}$ variation was not found to confer any effect on sepsis (38).

The ILIB SNP most studied is the $-31 C>\mathrm{T}(16-19,21,37,39)$. In mixed-ethnic burns patients from the USA (TBSA>15\%) this SNP seems to be no relevant risk factor for the development of sepsis nor for mortality $(16-19,21)$. In Han Chinese multiple trauma patients, however, the $I L 1 B-31 C>\mathrm{T}$ major CC genotype seemed to protect against sepsis $(30.3 \%$ and $37.9 \%)$ following major trauma $(37,39)$. 


\section{ILIRN}

In one study the effect of ILIRN variant 2 variable number tandem repeat (VNTR) polymorphism was studied in patients with traumatic brain injury (TBI) (Table 1) (40). ILIRN VNTR allele 2 carriers were more likely to have hemorrhagic events after TBI. In another study in severe trauma patients a ILIRN SNP 130T>C (rs315952), distinct from the welldescribed VNTR SNP, was associated with decreased risk of ARDS (41).

\section{Interleukin-4 (IL4)}

Two studies from the same hospital with overlapping patient cohorts reported the influence of IL4 -589T >C genotype in a cohort of 308 Chinese severe trauma patients with a mean ISS of 25.5 (Table 1) $(37,42)$. A total of $48.4 \%$ of patients developed sepsis. The frequency of the TC heterozygous genotype in the sepsis group (37.6\%) was significantly higher than in nonsepsis group $(25.2 \%)$. There was a significant influence of the minor $\mathrm{C}$ allele. No relationship was observed between IL4 -589T>C and MODS in these major trauma patients.

\section{Interleukin-6 (IL6)}

The IL6 -174G>C (rs1800795) was studied in three cohorts of burns patients (16-19, 43), six cohorts of trauma patients $(12,38,44-47)$ and a cohort of traumatic brain injury (TBI) patients (Table 1) (48). Only two out of these articles described an increased risk of sepsis with presence of the minor $-174 \mathrm{C}$ allele $(17,45)$. In a cohort of TBI patients the GG genotype was found significantly more frequently in the survivor group than in non-surviving patients (48).

Chinese trauma patients carrying the IL6 $-572 \mathrm{G}>\mathrm{C}$ CC genotype had significantly more sepsis morbidity than with a CG or GG genotype (37,46). A small Bosnian cohort however failed to demonstrate any influence of this SNP (47). 


\section{Interleukin-8 (IL8)}

The effect of IL8 -251A>T on the development of ARDS was studied in one cohort of 97 blunt trauma patients of whom 23 developed ARDS (Table 1) (49). The allele and genotype distribution of the polymorphism in this cohort did not exhibit a significant association with the development of ARDS or mortality. Patients with the AA genotype showed a significantly longer duration of mechanical ventilation compared to patients with the IL8 -251TT genotype.

\section{Interleukin-10 (IL10)}

The effects of IL10 -592A>C in trauma patients have been described in seven studies (Table 1) $(12,37,38,50-52)$. Three studies $(12,50,51)$ found conflicting results of genetic variation in this gene on outcome. Schröder et al. found an increased risk for MODS in -592AC genotypes. Huebinger et al. found that carriage of the minor -592A allele was associated with a decreased risk of mortality. McDaniel et al. found that patients carrying the IL10 ACC/ATA low producing genotypes were at a lower risk of developing sepsis.

IL10 -819C > T was studied in five cohorts of trauma patients $(12,37,43,50,52)$. Three studies describe an effect on outcome $(12,37,50)$. Huebinger et al. found that the minor $-819 \mathrm{~T}$ allele was significantly associated with a decreased risk of mortality. McDaniel et al. found that patients carrying the ILIO ACC/ATA low producing genotypes were at a lower risk of developing sepsis. In a cohort of Chinese trauma patients (where $\mathrm{C}$ appeared to be the minor allele) it was shown that this $\mathrm{C}$ allele conferred a decreased risk of sepsis (37).

IL10 $-1082 \mathrm{G}>\mathrm{A}$ was studied by ten authors $(12,36-38,43,51-55)$. Six authors observed effects on outcome $(12,36,38,52-54)$. McDaniel et al. (12) found that patients who carried the IL10 ACC/ATA low producing genotypes were at a lower risk of developing sepsis. Zeng et $a l$. , however, found that patients with the major A allele had significantly higher risk of sepsis (52). Jin et al. (54) as well as Schroeder et al. (38) described a reduced risk of ARDS and acute 
respiratory failure in GG genotypes. In contrast, Gong et al. found the $-1082 \mathrm{GG}$ genotype to be associated with an increased risk of ARDS in patients younger than 52 years old.

\section{Interleukin-17F (IL17F)}

Accardo Palumbo et al. studied the effect of 7488T $>\mathrm{C}$ (His161Arg)(rs763780) in ILI7 in a cohort of burns patients (Table 1) (43). At the third day, burn patients had a very significant increase in IL-17 plasma levels. However, there were no statistically significant differences in IL17 genotype distributions among patients that did or did not developed sepsis.

\section{Interleukin-18 (IL18)}

McDaniel et al. were unable to demonstrate a significant effect of SNPs in IL18 in trauma patients (Table 1) (12). Stassen et al. studied IL18-137G>C and IL18 -607C>A in 69 trauma patients (56). Although the individual SNPs were not associated with outcome, patients carrying both the -607CA genotype and a -137GC genotype (CA/GC) had a significantly reduced risk of sepsis. These data suggest that $I L 18$ genetic variability may play a role in the predisposition for the development of postinjury sepsis.

\subsection{Other Inflammatory Cytokines}

\section{High-Mobility Group Box 1 (HMGB1)}

Three $H M G B 1$ polymorphisms $-1514 \mathrm{~T}>\mathrm{C}, 2179 \mathrm{C}>\mathrm{G}$ and $6850 \mathrm{G}>\mathrm{A}$ were studied in a cohort of 556 Han Chinese patients with major trauma. A total of $39.7 \%$ of patients developed sepsis. The $H M G B 12179 \mathrm{C}>\mathrm{G}$ variant $\mathrm{GG}$ genotype predisposed to the occurrence of sepsis $(\mathrm{p}=0.003)$ and MODS ( $\mathrm{P}=0.011)$ in trauma patients (57). With respect to the other 2 SNPs, there were no significant differences in sepsis morbidity rates and MOD scores. 


\section{Interferon- $\gamma($ IFNG)}

In a mixed-ethnic cohort of 68 trauma patients (ISS > 15) of whom $42-50 \%$ developed sepsis (12) the IFNG 841T>A AA genotype protected against sepsis in African American patients, whereas this was not clear for Caucasian patients. The authors suggest that the carriage of the AA genotype could cause faster elimination of the pathogens (12). In an other cohort of 308 Han Chinese trauma patients (ISS $>16$ ) the IFNG $541 \mathrm{~T}>\mathrm{A}$ polymorphism was unrelated to sepsis or MOD (37).

\section{Tumor Necrosis Factor (TNF)}

Three SNPs in TNF have been studied in trauma and burns patients by nine authors (Table 1) $(12,16-19,21,37,58-62)$.

The TNF -308G>A (rs1800629) was described in burns patients by two authors in five studies $(16-19,21)$ and in trauma patients in eight studies $(12,15,19,37,58-62)$. Increased risk of sepsis and of mortality has been observed by seven authors $(16,17,19,37,58,61,62)$ but was not seen by four authors $(12,15,18,21,60)$. Moreover, Gill et al. demonstrated in a cohort of trauma patients that the A allele was significantly associated with the risk of microchimerism after allogenic transfusion of cells (59).

The TNF -238G>A (rs361525) was studied in trauma patients by one author (62). There was no influence of $-238 \mathrm{G}>\mathrm{A}$ variation on sepsis outcome in a cohort of 152 severely injured patients.

Also, the $T N F-376 \mathrm{G}>\mathrm{A}$ (rs1800750) was studied in trauma patients by one author (62). There was no influence of $-238 \mathrm{G}>\mathrm{A}$ variation on sepsis outcome outcome in a cohort of 152 severely injured patients. 


\section{Lymphotoxin- $\alpha($ LTA $)$}

Effects of variation in lymfotoxin- $\alpha$ LTA $252 \mathrm{~A}>\mathrm{G}$ (rs909253) (previously known as TNF- $\beta$ NcO1) was studied in trauma patients in five manuscripts $(45,58,60,61,63)$. Three authors observed an effect on clinical outcome $(60,61,63)$ and two did not $(45,58)$.

Majetschak et al. found that severe posttraumatic sepsis was significantly increased in patients homozygous for the allele TNFB2 (presently termed the A allele) (63). Three years later, Majetschak again found that patients developing severe sepsis after trauma were significantly more likely to be homozygous for $T N F B 2$ and this time also homozygous for TNFB1 (presently termed the $\mathrm{G}$ allele) (60). Menges et al. also found that carriage of the $\mathrm{G}$ allele (TNFB1) conferred an increased risk of developing sepsis (61). Hildebrand et al. (45) and Duan et al. (58) found no effect on sepsis morbidity. 


\section{CONCLUSION}

Severe injury or multiple trauma (the so-called 'first hit') evokes a systemic inflammatory response in trauma patients. In uncomplicated cases this response is temporary and predictable to a certain extent. If the initial hit however is big enough it may produce a Systemic Inflammatory Response Syndrome (SIRS). The following emergency damage-control surgery and later definitive surgical procedures (the 'second hit') may further exhaust the immune system potentially leading to immune paralysis causing the Compensatory Anti-inflammatory Response Syndrome (CARS). Several mechanisms contribute to the development of SIRS such as hormonal, metabolic, hemodynamic, immunological, cell-mediated and ischemia/reperfusion processes (64).

The outcome following major trauma is thus determined by many factors of which sequence variation in the human genome may well be one such factor. A number of genes have been studied so far but these studies are generally unique and numbers are often small. Outcome parameters of studies, as shown in this review are sometimes different making pooling of results or comparison complicated. Nevertheless, some single nucleotide polymorphisms clearly appear to exert an effect on the outcome.

Identifying patients at risk of developing infectious complications may improve their outcome by targeted treatments such as antibiotic prophylaxis, substitution therapy or plasma transfusions.

But unfortunately too little information is currently available to draw firm conclusions. Further research in this field is necessary. Since systemic response to trauma is a complex and polygenic phenotype, more genes will have to be studied in larger cohorts to determine their exact influence on outcome in severely injured patients. State-of-the-art techniques like exome sequencing and whole genome SNP arrays should be used in future studies in order to identify relevant sequence variations in other immune response genes and signalling pathways as well. 


\section{AUTHOR CONTRIBUTION STATEMENT}

\section{M.W.G.A. Bronkhorst, MD FEBS FRCS}

Study design. Literature search. Data analysis. Writing.

E.M.M. van Lieshout, MSc PhD

Study design. Data analysis. Writing. Critical revision.

P. Patka, MD PhD

Study design. Data interpretation. Critical revision. 
Supplemental Table S1. Summary of SNPs studied in populations of trauma patients

\begin{tabular}{|c|c|c|c|c|c|}
\hline Gene & OMIM & $\begin{array}{c}\text { Cytogenetic } \\
\text { Location }\end{array}$ & SNP & dbSNP ID & References \\
\hline \multicolumn{6}{|c|}{ Pattern Recognition Receptors and Complexes } \\
\hline \multirow[t]{3}{*}{ TLRI } & 601194 & $4 p 14$ & $-7202 A>G$ & rs5743551 & (9) \\
\hline & & & $742 \mathrm{~A}>\mathrm{G}$ & rs4833095 & (9) \\
\hline & & & $1804 \mathrm{G}>\mathrm{T}$ & rs5743618 & (9) \\
\hline \multirow[t]{6}{*}{ TLR2 } & 603028 & $4 q 31$ & $-15607 A>G$ & rs 1898830 & (10) \\
\hline & & & 19216T $>C$ & rs3804099 & (10) \\
\hline & & & $22215 \mathrm{~T} / \mathrm{G}$ & rs7656411 & (10) \\
\hline & & & p.R753Q & rs5743708 & $(11,12)$ \\
\hline & & & p.R753Q & rs5743708 & $(11,12)$ \\
\hline & & & $-16934 \mathrm{~T}>\mathrm{A}$ & rs4696480 & (11) \\
\hline \multirow[t]{8}{*}{$T L R 4$} & 603030 & $9 q 33$ & $-2381 A>G$ & rs2737190 & (13) \\
\hline & & & $-2242 \mathrm{~T}>\mathrm{C}$ & rs10116253 & (13) \\
\hline & & & $-1892 G>A$ & rs10983755 & (13) \\
\hline & & & $-1837 A>G$ & rs1927914 & (13) \\
\hline & & & $-1418 \mathrm{~T}>\mathrm{C}$ & rs10759932 & (13) \\
\hline & & & $11367 \mathrm{G}>\mathrm{C}$ & N.A. & (14) \\
\hline & & & $896 \mathrm{~A}>\mathrm{G}$ & rs4986790 & $(11,12,15-19)$ \\
\hline & & & $1196 \mathrm{~T}>\mathrm{C}$ & rs4986791 & $(11,12)$ \\
\hline \multirow[t]{5}{*}{ TLR9 } & 605474 & $3 \mathrm{p} 21$ & $-1486 \mathrm{~T}>\mathrm{C}$ & rs187084 & $(11,20)$ \\
\hline & & & $2848 \mathrm{C}>\mathrm{T}$ & rs352140 & (20) \\
\hline & & & $6577 \mathrm{~T}>\mathrm{C}$ & rs352162 & (20) \\
\hline & & & g. $6808 \mathrm{~A}>\mathrm{G}$ & rs352139 & \\
\hline & & & $-1237 \mathrm{~T}>\mathrm{C}$ & rs5743836 & (11) \\
\hline \multirow[t]{2}{*}{ CD 14} & 158120 & $5 q 31$ & $-159 C>T$ & rs 2569190 & $(11,16-19,21-26)$ \\
\hline & & & $-1145 \mathrm{G}>\mathrm{A}$ & rs 2569191 & $(24,26)$ \\
\hline LY96 & 605243 & $8 \mathrm{q} 21$ & $-1625 C>G$ & rs11465996 & $(27,28)$ \\
\hline
\end{tabular}




\begin{tabular}{|c|c|c|c|c|c|}
\hline$L B P$ & 151990 & 20q11 & $26877 \mathrm{~T}>\mathrm{C}$ & rs2232618 & (29) \\
\hline \multirow[t]{3}{*}{$M B L 2$} & 154545 & $10 q 21$ & Codon 52 & rs5030737 & (30) \\
\hline & & & Codon 54 & rs 1800450 & (30) \\
\hline & & & Codon 57 & rs 1800451 & (30) \\
\hline \multirow[t]{2}{*}{ MASP2 } & 605102 & & p.Y371D & rs12711521 & (30) \\
\hline & & & p.D120G & N.A. & (30) \\
\hline \multirow[t]{2}{*}{ FCN2 } & 601624 & & p.A258S & rs7851696 & (30) \\
\hline & & & p.T236M & rs17549193 & (30) \\
\hline \multirow[t]{4}{*}{$R A G E$} & 600214 & $6 \mathrm{p} 21$ & -407 to -345 & 63bp ins/del & (32) \\
\hline & & & $570 \mathrm{G}>\mathrm{A}$ & rs 2070600 & (32) \\
\hline & & & $-374 \mathrm{~T}>\mathrm{A}$ & rs 1800624 & (32) \\
\hline & & & $-429 \mathrm{~T}>\mathrm{C}$ & rs 1800625 & (32) \\
\hline \multirow[t]{2}{*}{ NLRP3 } & 606416 & $1 q 44$ & $-1017 \mathrm{G}>\mathrm{A}$ & rs 2027432 & (33) \\
\hline & & & $5134 \mathrm{~A}>\mathrm{G}$ & rs12048215 & (33) \\
\hline$h G R / N R 3 C 1$ & 138040 & $5 q 31$ & $\mathrm{Bcl}$ I C>G & rs41423247 & (34) \\
\hline \multicolumn{6}{|c|}{ Signal Transducing Adaptor Proteins } \\
\hline IRAKI & 300283 & $\mathrm{Xq} 28$ & $1595 \mathrm{~T}>\mathrm{C}$ & rs 1059703 & $(35)$ \\
\hline IRAK3 & 604459 & $12 q 14$ & 15SNPs & Ht Block 1 & (36) \\
\hline \multicolumn{6}{|c|}{ Inflammatory Cytokines } \\
\hline ILIA & 147760 & $2 q 13$ & $-889 \mathrm{C}>\mathrm{T}$ & rs 1800587 & $(37)$ \\
\hline \multirow[t]{4}{*}{ ILIB } & 147720 & $2 q 13$ & $3953 \mathrm{C}>\mathrm{T}$ & rs1143634 & $(38,45)$ \\
\hline & & & $-1470 \mathrm{G}>\mathrm{C}$ & N.A. & $(37,39)$ \\
\hline & & & $-511 \mathrm{~T}>\mathrm{C}$ & rs16944 & $(37-40)$ \\
\hline & & & $-31 \mathrm{C}>\mathrm{T}$ & rs1143627 & $(16-18,37,39)$ \\
\hline \multirow[t]{2}{*}{ ILIRN } & 147679 & $2 q 13$ & VNTR & rs315952 & $(40)$ \\
\hline & & & $\mathrm{C}>\mathrm{T}$ & rs315952C & $(41)$ \\
\hline IL4 & 147780 & $5 q 31$ & $-589 \mathrm{~T}>\mathrm{C}$ & rs 2243250 & $(37,42)$ \\
\hline \multirow[t]{2}{*}{ IL6 } & 147620 & $7 \mathrm{p} 15$ & $-174 \mathrm{G}>\mathrm{C}$ & rs1800795 & $\begin{array}{l}(12,16-19,36,38, \\
43,44,46-48)\end{array}$ \\
\hline & & & $-572 \mathrm{G}>\mathrm{C}$ & rs 1800796 & $(37,46,47)$ \\
\hline
\end{tabular}




\begin{tabular}{|c|c|c|c|c|c|}
\hline & & & $-597 \mathrm{G}>\mathrm{A}$ & rs1800797 & \\
\hline ILS & 146930 & $4 q 13$ & $-251 \mathrm{~A}>\mathrm{T}$ & rs4073 & (49) \\
\hline \multirow[t]{3}{*}{ ILIO } & 124092 & $1 q 32$ & $-1082 G>A$ & rs1800896 & $\begin{array}{c}(12,36-38,43,51- \\
55)\end{array}$ \\
\hline & & & $-819 \mathrm{C}>\mathrm{T}$ & rs 1800871 & $(12,37,43,50,52)$ \\
\hline & & & $-592 C>A$ & rs1800872 & $\begin{array}{c}(12,37,38,43,50- \\
52)\end{array}$ \\
\hline IL17F & 606496 & $6 \mathrm{p} 12$ & $7488 \mathrm{~T}>\mathrm{C}$ & rs763780 & (43) \\
\hline \multirow[t]{2}{*}{ IL18 } & 600953 & $11 \mathrm{q} 23$ & $-137 \mathrm{G}>\mathrm{C}$ & rs187238 & $(12,56)$ \\
\hline & & & $-607 C>A$ & rs 1946518 & $(12,56)$ \\
\hline \multirow[t]{3}{*}{$T N F$} & 191160 & $6 \mathrm{p} 21$ & $-308 \mathrm{G}>\mathrm{A}$ & rs 1800629 & $\begin{array}{c}(12,15-19,21,37 \\
58-62)\end{array}$ \\
\hline & & & $-238 G>A$ & rs361525 & (62) \\
\hline & & & $-376 \mathrm{G}>\mathrm{A}$ & rs 1800750 & (62) \\
\hline LTA & 153440 & $6 \mathrm{p} 21$ & $252 \mathrm{~A}>\mathrm{G}$ & rs909253 & $(45,58,60,61,63)$ \\
\hline IFNG & 147570 & $12 q 15$ & $874 \mathrm{~T}>\mathrm{A}$ & rs2430561 & $(12,37)$ \\
\hline \multirow[t]{3}{*}{ HMGB1 } & 163905 & $13 q 12$ & $-1514 \mathrm{~T}>\mathrm{C}$ & rs 1412125 & 77 \\
\hline & & & $2179 \mathrm{C}>\mathrm{G}$ & rs2249825 & (57) \\
\hline & & & $6850 \mathrm{G}>\mathrm{A}$ & rs 1045411 & (57) \\
\hline \multicolumn{6}{|c|}{ Other Genes not belonging to the Innate Immune System } \\
\hline \multirow[t]{3}{*}{ MYLK } & 600922 & $3 q 21$ & p.P21H & rs28497577 & $(65)$ \\
\hline & & & p.S147P & rs9840993 & $(65)$ \\
\hline & & & & rs4678047 & $(65)$ \\
\hline PRDX6 & 602316 & $1 \mathrm{q} 25$ & & 43 SNPs & $(66)$ \\
\hline HSPA1B & 603012 & $6 \mathrm{p} 21$ & $1538 \mathrm{~A}>\mathrm{G}$ & N.A. & $(67)$ \\
\hline HSPA1L & 140559 & $6 \mathrm{p} 21$ & $2437 \mathrm{C}>\mathrm{T}$ & rs2075800 & $(67)$ \\
\hline HSP90B1 & 191175 & $12 q 23$ & $-144 C>A$ & rs9472238 & (68) \\
\hline SERPINE1 & 173360 & $7 q 22$ & -688 & rs1799768 & $(18,69)$ \\
\hline VEGFA & 192240 & $6 \mathrm{p} 21$ & & Ht Block 1 & (36) \\
\hline$A N G P T 2$ & 601922 & $8 \mathrm{p} 23$ & $127635 \mathrm{~T}>\mathrm{A}$ & rs 1868554 & (70) \\
\hline
\end{tabular}




\begin{tabular}{|l|c|c|c|c|c|}
\hline & & 135709T $>\mathrm{C}$ & $\mathrm{rs} 2442598$ & \\
\hline mtDNA & & mtDNA & T4216C & & \\
\hline MicroRNA & & stem-loop 37/5p +22 & G>C & rs4919510 & (71) \\
\hline
\end{tabular}


Supplemental Table S2. Detailed overview of association with outcome for SNPs in the TLR, CD14, IL, and TNF genes of trauma patients

\begin{tabular}{|c|c|c|c|c|c|c|c|c|c|c|c|c|}
\hline Gene & SNP & dbSNP ID & Author & Year & Population & $\mathbf{N}$ & SIRS & Sepsis & Septic Shock & MODS & Mortality & References \\
\hline \multirow[t]{3}{*}{$T L R 1$} & $-7202 A>G$ & rs5743551 & Thompson & 2013 & Whites & 1498 & - & + & + & + & $\uparrow \mathrm{G}$ allele & (9) \\
\hline & $742 \mathrm{~A}>\mathrm{G}$ & rs4833095 & Thompson & 2013 & Whites & 1498 & - & + & + & + & $\uparrow \mathrm{G}$ allele & (9) \\
\hline & $1804 \mathrm{G}>\mathrm{T}$ & rs5743618 & Thompson & 2013 & Whites & 1498 & - & + & + & + & $\uparrow \mathrm{T}$ allele & (9) \\
\hline \multirow[t]{5}{*}{ TLR2 } & $-15607 \mathrm{~A}>\mathrm{G}$ & rs1898830 & Chen & 2011 & Han Chinese & 410 & - & + & + & + & - & (10) \\
\hline & $19216 \mathrm{~T}>\mathrm{C}$ & rs3804099 & Chen & 2011 & Han Chinese & 410 & - & $\uparrow \mathrm{C}$ allele & - & $\uparrow \mathrm{C}$ allele & - & (10) \\
\hline & $22215 \mathrm{~T} / \mathrm{G}$ & rs7656411 & Chen & 2011 & Han Chinese & 410 & - & + & - & + & - & (10) \\
\hline & p.R753Q & rs5743708 & Bronkhorst & 2013 & Mixed Ethnic & 219 & + & + & + & + & + & (11) \\
\hline & & rs5743708 & McDaniel & 2007 & Mixed Ethnic & 68 & - & $\uparrow \mathrm{AG}$ & - & - & - & (12) \\
\hline \multirow[t]{7}{*}{ TLR4 } & $-2381 A>G$ & rs2737190 & Chen & 2010 & Han Chinese & 303 & - & + & - & + & - & (13) \\
\hline & $-2242 \mathrm{~T}>\mathrm{C}$ & rs10116253 & Chen & 2010 & Han Chinese & 303 & - & $\uparrow \mathrm{C}$ allele & - & $\uparrow \mathrm{C}$ allele & - & (13) \\
\hline & $-1892 \mathrm{G}>\mathrm{A}$ & rs10983755 & Chen & 2010 & Han Chinese & 303 & - & + & - & + & - & (13) \\
\hline & $-1837 A>G$ & rs1927914 & Chen & 2010 & Han Chinese & 303 & - & + & - & + & - & (13) \\
\hline & $-1418 \mathrm{~T}>\mathrm{C}$ & rs10759932 & Chen & 2010 & Han Chinese & 303 & - & + & - & + & - & (13) \\
\hline & $11367 \mathrm{G}>\mathrm{C}$ & N.A. & Duan & 2009 & Han Chinese & 132 & - & $\downarrow \mathrm{C}$ allele & - & $\downarrow$ C allele & - & (14) \\
\hline & $896 A>G$ & rs4986790 & Bronkhorst & 2013 & Mixed Ethnic & 219 & + & + & + & + & + & (11) \\
\hline
\end{tabular}




\begin{tabular}{|c|c|c|c|c|c|c|c|c|c|c|c|c|}
\hline & & & McDaniel & 2007 & Mixed Ethnic & 68 & - & + & - & - & - & (12) \\
\hline & & & Shalhub & 2009 & Whites & 598 & + & $\downarrow$ A allele & + & + & + & (15) \\
\hline & & & Barber & 2004 & Mixed Ethnic & 159 & - & + & $\uparrow \mathrm{G}$ allele & - & - & (16) \\
\hline & & & Barber & 2006 & Mixed Ethnic & 228 & & + & $\uparrow \mathrm{G}$ allele & & & (17) \\
\hline & & & Barber & 2008 & Mixed Ethnic & 149 & - & + & + & + & + & (18) \\
\hline & & & Shalhub & 2009 & Mixed Ethnic & 69 & - & + & + & + & + & (19) \\
\hline & 1196T $>C$ & rs4986791 & Bronkhorst & 2013 & Mixed Ethnic & 219 & + & + & + & + & + & (11) \\
\hline & & & McDaniel & 2007 & Mixed Ethnic & 68 & - & + & - & - & - & (12) \\
\hline TLR9 & $-1486 \mathrm{~T}>\mathrm{C}$ & rs187084 & Bronkhorst & 2013 & Mixed Ethnic & 219 & + & + & + & + & + & (11) \\
\hline & & & Chen & 2011 & Han Chinese & 557 & - & $\uparrow \mathrm{G}$ allele & + & + & - & (20) \\
\hline & $2848 \mathrm{C}>\mathrm{T}$ & rs352140 & Chen & 2011 & Han Chinese & 557 & - & + & + & + & - & (20) \\
\hline & $6577 \mathrm{~T}>\mathrm{C}$ & rs 352162 & Chen & 2011 & Han Chinese & 557 & - & $\uparrow \mathrm{C}$ allele & + & + & - & (20) \\
\hline & g. $6808 \mathrm{~A}>\mathrm{G}$ & rs352139 & Chen & 2011 & Han Chinese & 557 & - & $\uparrow \mathrm{G}$ allele & + & + & - & (20) \\
\hline & $-1237 \mathrm{~T}>\mathrm{C}$ & rs5743836 & Bronkhorst & 2013 & Mixed Ethnic & 219 & + & + & + & + & + & (11) \\
\hline CD 14 & $-159 \mathrm{C}>\mathrm{T}$ & rs2569190 & Bronkhorst & 2013 & Mixed Ethnic & 219 & + & + & + & + & + & (11) \\
\hline & & & Barber & 2004 & Mixed Ethnic & 159 & - & + & + & - & - & (16) \\
\hline & & & Barber & 2006 & Mixed Ethnic & 228 & - & + & $\uparrow \mathrm{C}$ allele & - & - & (17) \\
\hline & & & Barber & 2008 & Mixed Ethnic & 149 & - & + & + & + & $\uparrow \mathrm{C}$ allele & (18) \\
\hline & & & Shalhub & 2009 & Mixed Ethnic & 69 & - & + & + & + & + & (19) \\
\hline
\end{tabular}




\begin{tabular}{|c|c|c|c|c|c|c|c|c|c|c|c|c|}
\hline & & & Barber & 2007 & Mixed Ethnic & 223 & - & + & + & + & $\uparrow \mathrm{C}$ allele & (21) \\
\hline & & & Dong & 2010 & Chinese & 35 & - & $\uparrow \mathrm{T}$ allele & + & - & - & (22) \\
\hline & & & Dong & 2009 & Chinese & 77 & - & $\uparrow \mathrm{T}$ allele & - & $\uparrow \mathrm{T}$ allele & - & (23) \\
\hline & & & $\mathrm{Gu}$ & 2010 & Han Chinese & 105 & - & $\uparrow \mathrm{T}$ allele & - & $\uparrow \mathrm{T}$ allele & - & (24) \\
\hline & & & Heesen & 2010 & Unknown & 58 & - & + & + & + & + & $(25)$ \\
\hline & & & Liu & 2011 & Chinese & 106 & - & - & - & $\uparrow \mathrm{T}$ allele & - & (26) \\
\hline & $-1145 G>A$ & rs2569191 & $\mathrm{Gu}$ & 2010 & Han Chinese & 105 & - & $\uparrow \mathrm{G}$ allele & - & $\uparrow \mathrm{G}$ allele & - & (26) \\
\hline & & & Liu & 2011 & Chinese & 106 & - & + & - & $\uparrow \mathrm{G}$ allele & - & (24) \\
\hline ILIA & $-889 C>T$ & rs1800587 & $\mathrm{Gu}$ & 2010 & Han Chinese & 308 & - & $\uparrow \mathrm{T}$ allele & - & $\uparrow \mathrm{C}$ allele & - & (37) \\
\hline \multirow[t]{10}{*}{ ILIB } & $3953 \mathrm{C}>\mathrm{T}$ & rs1143634 & Schroeder & 2008 & Caucasian & 100 & - & - & - & - & + & (38) \\
\hline & & & Hildebrand & 2005 & Unknown & 97 & + & + & + & + & + & (45) \\
\hline & $-1470 \mathrm{G}>\mathrm{C}$ & N.A. & $\mathrm{Gu}$ & 2010 & Han Chinese & 308 & - & $\uparrow \mathrm{G}$ allele & - & + & - & (37) \\
\hline & & & Wen & 2010 & Han Chinese & 238 & - & $\uparrow \mathrm{G}$ allele & + & + & - & (39) \\
\hline & $-511 \mathrm{~T}>\mathrm{C}$ & rs16944 & $\mathrm{Gu}$ & 2010 & Han Chinese & 308 & - & $\uparrow \mathrm{C}$ allele & - & + & - & (37) \\
\hline & & & Schroeder & 2008 & Caucasian & 100 & - & - & - & - & + & (38) \\
\hline & & & Wen & 2010 & Han Chinese & 238 & - & $\uparrow \mathrm{C}$ allele & + & + & - & (39) \\
\hline & & & Hadjigeorgiou & 2005 & Greek & 183 & - & - & - & - & - & (40) \\
\hline & $-31 C>T$ & rs1143627 & Barber & 2004 & Mixed Ethnic & 159 & - & + & + & - & - & (16) \\
\hline & & & Barber & 2006 & Mixed Ethnic & 228 & & + & + & - & - & (17) \\
\hline
\end{tabular}




\begin{tabular}{|c|c|c|c|c|c|c|c|c|c|c|c|c|}
\hline & & & Barber & 2008 & Mixed Ethnic & 149 & - & + & + & + & + & $(18)$ \\
\hline & & & $\mathrm{Gu}$ & 2010 & Han Chinese & 308 & - & $\uparrow \mathrm{T}$ allele & - & + & - & (37) \\
\hline & & & Wen & 2010 & Han Chinese & 238 & - & $\uparrow \mathrm{T}$ allele & + & + & - & (39) \\
\hline \multirow[t]{2}{*}{ ILIRN } & VNTR & rs315952 & Hadjigeorgiou & 2005 & Greek & 183 & - & - & - & - & - & $(40)$ \\
\hline & $\mathrm{C}>\mathrm{T}$ & rs315952C & Meyer & 2013 & European & 778 & - & + & + & - & + & $(41)$ \\
\hline \multirow[t]{2}{*}{ IL4 } & $-589 \mathrm{~T}>\mathrm{C}$ & rs2243250 & $\mathrm{Gu}$ & 2010 & Han Chinese & 308 & - & $\uparrow \mathrm{C}$ allele & - & + & - & (37) \\
\hline & & & $\mathrm{Gu}$ & 2011 & Han Chinese & 308 & - & $\uparrow \mathrm{C}$ allele & - & - & - & $(42)$ \\
\hline \multirow[t]{12}{*}{ IL6 } & $-174 G>C$ & rs1800795 & McDaniel & 2007 & Mixed Ethnic & 68 & - & + & - & - & - & (12) \\
\hline & & & Barber & 2004 & Mixed Ethnic & 159 & - & + & + & - & - & (16) \\
\hline & & & Barber & 2006 & Mixed Ethnic & 228 & - & + & + & - & + & $(17)$ \\
\hline & & & Barber & 2008 & Mixed Ethnic & 149 & - & + & + & + & + & $(18)$ \\
\hline & & & Shalhub & 2009 & Mixed Ethnic & 69 & - & + & + & + & + & (19) \\
\hline & & & Meyer & 2012 & Mixed Ethnic & 474 & - & - & - & + & + & (36) \\
\hline & & & Schroeder & 2008 & Caucasian & 119 & - & - & - & - & + & $(38)$ \\
\hline & & & Accardo & 2012 & Unknown & 71 & - & + & + & + & + & (43) \\
\hline & & & Heesen & 2002 & Caucasian & 57 & - & + & + & + & - & (44) \\
\hline & & & $\mathrm{Gu}$ & 2008 & Han Chinese & 105 & - & - & - & + & - & (46) \\
\hline & & & Jeremic & 2014 & Unknown & 47 & - & + & + & + & + & (47) \\
\hline & & & Dalla Libera & 2011 & Unknown & 77 & - & - & - & + & $\downarrow$ G allele & $(48)$ \\
\hline
\end{tabular}




\begin{tabular}{|c|c|c|c|c|c|c|c|c|c|c|c|c|}
\hline & $-572 G>C$ & rs1800796 & $\mathrm{Gu}$ & 2010 & Han Chinese & 308 & - & $\uparrow \mathrm{C}$ allele & - & + & - & (37) \\
\hline & & & $\mathrm{Gu}$ & 2008 & Han Chinese & 105 & - & $\downarrow$ G allele & - & + & - & (46) \\
\hline & & & Jeremic & 2014 & Unknown & 47 & - & + & + & + & + & (47) \\
\hline & $-597 G>A$ & rs1800797 & $\mathrm{Gu}$ & 2008 & Han Chinese & 105 & - & - & - & - & - & (46) \\
\hline IL8 & $-251 \mathrm{~A}>\mathrm{T}$ & rs4073 & Hildebrand & 2007 & Unknown & 97 & - & + & + & + & + & (49) \\
\hline \multirow[t]{14}{*}{ ILIO } & $-1082 G>A$ & rs1800896 & McDaniel & 2007 & Mixed Ethnic & 68 & - & $\uparrow \mathrm{G}$ allele & - & - & - & (12) \\
\hline & & & Meyer & 2012 & Mixed Ethnic & 474 & - & - & - & + & + & (36) \\
\hline & & & $\mathrm{Gu}$ & 2010 & Han Chinese & 308 & - & + & - & + & - & (37) \\
\hline & & & Schroeder & 2008 & Caucasian & 100 & - & - & - & - & + & (38) \\
\hline & & & Accardo & 2012 & Unknown & 71 & - & $\uparrow \mathrm{G}$ allele & + & + & + & (43) \\
\hline & & & Schröder & 2004 & Unknown & 119 & - & + & - & + & + & (51) \\
\hline & & & Zeng & 2009 & Han Chinese & 308 & - & $\uparrow$ A allele & + & + & + & (52) \\
\hline & & & Gong & 2006 & Caucasian & 211 & - & - & - & - & $\downarrow G$ allele & (53) \\
\hline & & & Jin & 2012 & Chinese & 29 & - & - & - & - & $\downarrow$ G allele & (54) \\
\hline & $-819 C>T$ & rs1800871 & McDaniel & 2007 & Mixed Ethnic & 68 & - & + & - & - & - & (12) \\
\hline & & & $\mathrm{Gu}$ & 2010 & Han Chinese & 308 & - & $\uparrow \mathrm{T}$ allele & - & + & - & (37) \\
\hline & & & Accardo & 2012 & Unknown & 71 & - & - & + & + & + & (43) \\
\hline & & & Huebinger & 2010 & Mixed Ethnic & 265 & - & + & - & + & $\downarrow \mathrm{T}$ allele & (50) \\
\hline & & & Zeng & 2009 & Han Chinese & 308 & - & + & + & + & + & (52) \\
\hline
\end{tabular}




\begin{tabular}{|c|c|c|c|c|c|c|c|c|c|c|c|c|}
\hline & $-592 C>A$ & rs1800872 & McDaniel & 2007 & Mixed Ethnic & 68 & - & + & - & - & - & (12) \\
\hline & & & $\mathrm{Gu}$ & 2010 & Han Chinese & 308 & - & + & - & + & - & (37) \\
\hline & & & Schroeder & 2008 & Caucasian & 100 & - & + & - & - & + & (38) \\
\hline & & & Accardo & 2012 & Unknown & 71 & - & - & + & + & + & (43) \\
\hline & & & Huebinger & 2010 & Mixed Ethnic & 265 & - & + & - & + & $\downarrow$ A allele & $(50)$ \\
\hline & & & Schröder & 2004 & Unknown & 119 & - & + & - & $\uparrow \mathrm{AC}$ & + & (51) \\
\hline & & & Zeng & 2009 & Han Chinese & 308 & - & + & + & + & + & (52) \\
\hline IL17F & 7488T $>C$ & rs763780 & Accardo & 2012 & Unknown & 71 & - & - & + & + & + & (43) \\
\hline \multirow[t]{4}{*}{ IL18 } & $-137 G>C$ & rs187238 & McDaniel & 2007 & Mixed Ethnic & 68 & - & + & - & - & - & (12) \\
\hline & & & Stassen & 2003 & Mixed Ethnic & 66 & - & + & + & + & + & (56) \\
\hline & $-607 C>A$ & rs1946518 & McDaniel & 2007 & Mixed Ethnic & 68 & - & + & - & - & - & (12) \\
\hline & & & Stassen & 2003 & Mixed Ethnic & 66 & - & + & + & + & + & (56) \\
\hline \multirow[t]{7}{*}{$T N F$} & $-308 G>A$ & rs1800629 & McDaniel & 2007 & Mixed Ethnic & 68 & - & + & - & - & - & (12) \\
\hline & & & Barber & 2004 & Mixed Ethnic & 159 & - & $\uparrow \mathrm{A}$ allele & + & - & - & (16) \\
\hline & & & Barber & 2006 & Mixed Ethnic & 228 & - & $\uparrow \mathrm{A}$ allele & + & - & + & (17) \\
\hline & & & Barber & 2008 & Mixed Ethnic & 149 & - & + & + & + & + & (18) \\
\hline & & & Shalhub & 2009 & Mixed Ethnic & 69 & - & $\uparrow \mathrm{A}$ allele & + & + & + & (19) \\
\hline & & & Shalhub & 2009 & Mixed Ethnic & 598 & - & + & + & + & + & (15) \\
\hline & & & Barber & 2007 & Mixed Ethnic & 223 & - & + & + & + & + & (21) \\
\hline
\end{tabular}




\begin{tabular}{|c|c|c|c|c|c|c|c|c|c|c|c|}
\hline & & $\mathrm{Gu}$ & 2010 & Han Chinese & 308 & - & $\uparrow \mathrm{A}$ allele & - & + & - & (37) \\
\hline & & Duan & 2011 & Han Chinese & 306 & - & $\uparrow \mathrm{A}$ allele & + & + & + & $(58)$ \\
\hline & & Gill & 2008 & Unknown & 59 & - & - & - & - & - & $(59)$ \\
\hline & & Majetschak & 2002 & Unknown & 70 & - & + & + & - & + & $(60)$ \\
\hline & & Menges & 2008 & Unknown & 159 & - & $\uparrow \mathrm{A}$ allele & + & + & $\uparrow \mathrm{A}$ allele & (61) \\
\hline & & O'Keefe & 2002 & Unknown & 152 & - & $\uparrow \mathrm{A}$ allele & + & + & $\uparrow \mathrm{A}$ allele & $(62)$ \\
\hline$-238 G>A$ & rs361525 & O'Keefe & 2002 & Unknown & 152 & - & + & + & + & + & $(62)$ \\
\hline$-376 \mathrm{G}>A$ & rs1800750 & O'Keefe & 2002 & Unknown & 152 & - & + & + & + & + & $(62)$ \\
\hline
\end{tabular}

+: $\quad$ outcome parameter was studied

-: $\quad$ outcome parameter was not studied

$\uparrow \downarrow: \quad$ genotype was positively/negatively associated with outcome parameter 
Table 1. Overview of association with outcome for SNPs in the $T L R, C D 14, I L$, and $T N F$ genes of trauma patients

\begin{tabular}{|c|c|c|c|c|c|c|c|c|}
\hline Gene & $\begin{array}{c}\text { Number of } \\
\text { SNPs studied }\end{array}$ & $\begin{array}{c}\text { Number of } \\
\text { patients studied }\end{array}$ & $\overline{\text { SIRS }}$ & Sepsis & Septic Shock & MODS & Mortality & References \\
\hline$\overline{T L R 1}$ & 3 & 1498 & - & + & + & + & $\uparrow(3 \mathrm{SNPs})$ & (9) \\
\hline$T L R 2$ & 5 & 697 & $\uparrow(1 \mathrm{SNP})$ & $\uparrow(2$ SNPs) & + & $\uparrow(1 \mathrm{SNP})$ & + & $(10-12)$ \\
\hline TLR4 & 8 & 1925 & + & $\uparrow(1 \mathrm{SNP}) \downarrow(2 \mathrm{SNPs})$ & $\uparrow(1 \mathrm{SNP})$ & $\uparrow(1 \mathrm{SNP}) \downarrow(1 \mathrm{SNP})$ & + & $(11-19)$ \\
\hline TLR9 & 5 & 776 & + & $\uparrow(3 \mathrm{SNPs})$ & + & + & + & $(11,20)$ \\
\hline CD 14 & 2 & 1428 & + & $\uparrow(2$ SNPs) & $\uparrow(1 \mathrm{SNP})$ & $\uparrow(2$ SNPs $)$ & $\uparrow(1 \mathrm{SNP})$ & $(11,16-19,21-26)$ \\
\hline ILIA & 1 & 308 & - & $\uparrow(1 \mathrm{SNP})$ & - & $\uparrow(1 \mathrm{SNP})$ & - & 37 \\
\hline ILIB & 4 & 1462 & + & $\uparrow(3 \mathrm{SNPs})$ & + & + & + & $(16-18,37-40,45)$ \\
\hline$I L 1 R N$ & 2 & 961 & - & + & + & - & + & $(40,41)$ \\
\hline IL4 & 1 & 308 & - & $\uparrow(1 \mathrm{SNP})$ & - & + & - & $(37,42)$ \\
\hline IL6 & 3 & 1931 & - & $\uparrow(1 \mathrm{SNP}) \downarrow(1 \mathrm{SNPs})$ & + & + & $\downarrow$ (1 SNPs) & $(12,16-19,36-38,43,44,46-48)$ \\
\hline IL8 & 1 & 97 & - & + & + & + & + & (49) \\
\hline ILI0 & 3 & 1953 & - & $\uparrow(2$ SNPs $)$ & + & $\uparrow(1 \mathrm{SNP})$ & $\downarrow$ (3 SNPs) & $(12,36-38,43,50-55)$ \\
\hline IL17F & 1 & 71 & - & - & + & + & + & (43) \\
\hline IL18 & 2 & 134 & - & + & + & + & + & $(12,56)$ \\
\hline TNF & 3 & 2548 & - & $\uparrow(1 \mathrm{SNP})$ & + & + & $\uparrow(1 \mathrm{SNP})$ & $(12,15-19,21,37,58-62)$ \\
\hline
\end{tabular}




\section{REFERENCES}

1. Norton R, Kobusingye O: Injuries. N Engl J Med 368(18):1723-1730, 2013.

2. Lozano R, Naghavi M, Foreman K, Lim S, Shibuya K, Aboyans V, Abraham J, Adair T, Aggarwal R, Ahn SY, et al.: Global and regional mortality from 235 causes of death for 20 age groups in 1990 and 2010: a systematic analysis for the Global Burden of Disease Study 2010. Lancet 380(9859):2095-2128, 2012.

3. Mann EA, Baun MM, Meininger JC, Wade CE: Comparison of mortality associated with sepsis in the burn, trauma, and general intensive care unit patient: a systematic review of the literature. Shock 37(1):4-16, 2012.

4. Wafaisade A, Lefering R, Bouillon B, Sakka SG, Thamm OC, Paffrath T, Neugebauer E, Maegele M, Trauma Registry of the German Society for Trauma S: Epidemiology and risk factors of sepsis after multiple trauma: an analysis of 29,829 patients from the Trauma Registry of the German Society for Trauma Surgery. Crit Care Med 39(4):621-628, 2011.

5. Sauaia A, Moore EE, Johnson JL, Chin TL, Banerjee A, Sperry JL, Maier RV, Burlew CC: Temporal trends of postinjury multiple-organ failure: still resource intensive, morbid, and lethal. The journal of trauma and acute care surgery 76(3):582-592, discussion 592-583, 2014.

6. Ni Choileain N, Redmond HP: The immunological consequences of injury. The surgeon : journal of the Royal Colleges of Surgeons of Edinburgh and Ireland 4(1):23-31, 2006.

7. Marik PE, Flemmer M: The immune response to surgery and trauma: Implications for treatment. The journal of trauma and acute care surgery 73(4):801-808, 2012.

8. Arcaroli J, Fessler MB, Abraham E: Genetic polymorphisms and sepsis. Shock 24(4):300-312, 2005.

9. Thompson CM, Holden TD, Rona G, Laxmanan B, Black RA, O'Keefe GE, Wurfel MM: Toll-Like Receptor 1 Polymorphisms and Associated Outcomes in Sepsis After Traumatic Injury: A Candidate Gene Association Study. Annals of surgery 259(1):179-185, 2013.

10. Chen KH, Gu W, Zeng L, Jiang DP, Zhang LY, Zhou J, Du DY, Hu P, Liu Q, Huang SN, et al.: Identification of haplotype tag SNPs within the entire TLR2 gene and their clinical relevance in patients with major trauma. Shock 35(1):35-41, 2011.

11. Bronkhorst MWGA, Boye ND, Lomax MAZ, Vossen RHAM, Bakker J, Patka P, Van Lieshout EMM: Single-nucleotide polymorphisms in the Toll-like receptor pathway increase susceptibility to infections in severely injured trauma patients. The journal of trauma and acute care surgery 74(3):862870, 2013. 
12. McDaniel DO, Hamilton J, Brock M, May W, Calcote L, Tee LY, Vick L, Newman DB, Vick K, Harrison S, et al.: Molecular analysis of inflammatory markers in trauma patients at risk of postinjury complications. J Trauma 63(1):147-157; discussion 157-148, 2007.

13. Chen K, Wang YT, Gu W, Zeng L, Jiang DP, Du DY, Hu P, Duan ZX, Liu Q, Huang SN, et al.: Functional significance of the Toll-like receptor 4 promoter gene polymorphisms in the Chinese Han population. Crit Care Med 38(5):1292-1299, 2010.

14. Duan ZX, Gu W, Zhang LY, Du DY, Hu P, Huang J, Liu Q, Wang ZG, Hao J, Jiang JX: Clinical relevance of the TLR4 11367 polymorphism in patients with major trauma. Arch Surg 144(12):1144$1148,2009$.

15. Shalhub S, Junker CE, Imahara SD, Mindrinos MN, Dissanaike S, O'Keefe GE: Variation in the TLR4 gene influences the risk of organ failure and shock posttrauma: a cohort study. J Trauma 66(1):115-122; discussion 122-113, 2009.

16. Barber RC, Aragaki CC, Rivera-Chavez FA, Purdue GF, Hunt JL, Horton JW: TLR4 and TNF-alpha polymorphisms are associated with an increased risk for severe sepsis following burn injury. Journal of medical genetics 41(11):808-813, 2004.

17. Barber RC, Chang LY, Arnoldo BD, Purdue GF, Hunt JL, Horton JW, Aragaki CC: Innate immunity SNPs are associated with risk for severe sepsis after burn injury. Clin Med Res 4(4):250-255, 2006.

18. Barber RC, Chang LY, Lemaire SM, Burris A, Purdue GF, Hunt JL, Arnoldo BD, Horton JW: Epistatic interactions are critical to gene-association studies: PAI-1 and risk for mortality after burn injury. Journal of burn care \& research : official publication of the American Burn Association 29(1):168-175, 2008.

19. Shalhub S, Pham TN, Gibran NS, O'Keefe G E: Tumor necrosis factor gene variation and the risk of mortality after burn injury: a cohort study. Journal of burn care \& research : official publication of the American Burn Association 30(1):105-111, 2009.

20. Chen KH, Zeng L, Gu W, Zhou J, Du DY, Jiang JX: Polymorphisms in the toll-like receptor 9 gene associated with sepsis and multiple organ dysfunction after major blunt trauma. The British journal of surgery 98(9):1252-1259, 2011.

21. Barber RC, Aragaki CC, Chang LY, Purdue GF, Hunt JL, Arnoldo BD, Horton JW: CD14-159 C allele is associated with increased risk of mortality after burn injury. Shock 27(3):232-237, 2007.

22. Dong N, Yao YM, Huang XJ, He LX, Yu Y, Sheng ZY: [Influence of CD14 gene polymorphism on the expression of high mobility group box-1 protein in patients with severe burn]. Zhonghua shao shang za zhi = Zhonghua shaoshang zazhi = Chinese journal of burns 26(2):109-112, 2010.

23. Dong N, Yao YM, Yu Y, Cao YJ, Sheng ZY: [Distribution and clinical significance of CD14 promoter-159C/T polymorphism in patients with extensive burn]. Zhonghua shao shang za zhi = Zhonghua shaoshang zazhi = Chinese journal of burns 25(2):115-118, 2009. 
24. Gu W, Dong H, Jiang DP, Zhou J, Du DY, Gao JM, Yao YZ, Zhang LY, Wen AQ, Liu Q, et al.:

Functional significance of CD14 promoter polymorphisms and their clinical relevance in a Chinese Han population. Crit Care Med 36(8):2274-2280, 2008.

25. Heesen M, Bloemeke B, Schade U, Obertacke U, Majetschak M: The -260 C-->T promoter polymorphism of the lipopolysaccharide receptor CD14 and severe sepsis in trauma patients. Intensive care medicine 28(8):1161-1163, 2002.

26. Liu Y, Du DY, Hu X, Xiang XY, Xia DK, Gu W, Jiang JX, Liu CB, Qin WC: [Association between the polymorphisms of cluster of differentiation 14 gene promoters and the susceptibility of multiple organ dysfunction syndrome after severe chest trauma]. Zhongguo yi xue ke xue yuan xue bao Acta Academiae Medicinae Sinicae 33(4):362-366, 2011.

27. Zeng L, Zhang AQ, Gu W, Zhou J, Zhang LY, Du DY, Zhang M, Wang HY, Jiang JX: Identification of haplotype tag SNPs within the whole myeloid differentiation 2 gene and their clinical relevance in patients with major trauma. Shock 37(4):366-372, 2012.

28. Gu W, Shan YA, Liu Q, Zhou J, Jiang DP, Yao YZ, Zhang LY, Du DY, Gao JM, Dong H, et al.: [Relationship of myeloid differentiation-2 gene promoter polymorphisms with susceptivity of complications after severe trauma in Chinese Han population]. Zhongguo yi xue ke xue yuan xue bao Acta Academiae Medicinae Sinicae 29(4):484-487, 2007.

29. Zeng L, Gu W, Zhang AQ, Zhang M, Zhang LY, Du DY, Huang SN, Jiang JX: A functional variant of lipopolysaccharide binding protein predisposes to sepsis and organ dysfunction in patients with major trauma. Annals of surgery 255(1):147-157, 2012.

30. Bronkhorst MWGA, Lomax MAZ, Vossen RHAM, Bakker J, Patka P, van Lieshout EMM: Risk of infection and sepsis in severely injured patients related to single nucleotide polymorphisms in the lectin pathway. The British journal of surgery 100(13):1818-1826, 2013.

31. Moller-Kristensen M, Ip WK, Shi L, Gowda LD, Hamblin MR, Thiel S, Jensenius JC, Ezekowitz RA, Takahashi K: Deficiency of mannose-binding lectin greatly increases susceptibility to postburn infection with Pseudomonas aeruginosa. J Immunol 176(3):1769-1775, 2006.

32. Zeng L, Zhang AQ, Gu W, Zhou J, Zhang LY, Du DY, Zhang M, Wang HY, Yan J, Yang C, et al.: Identification of haplotype tag single nucleotide polymorphisms within the receptor for advanced glycation end products gene and their clinical relevance in patients with major trauma. Critical care 16(4):R131, 2012.

33. Zhang AQ, Zeng L, Gu W, Zhang LY, Zhou J, Jiang DP, Du DY, Hu P, Yang C, Yan J, et al.: Clinical relevance of single nucleotide polymorphisms within the entire NLRP3 gene in patients with major blunt trauma. Critical care 15(6):R280, 2011. 
34. Duan ZX, Gu W, Du DY, Hu P, Jiang DP, Zhu PF, Wang ZG, Jiang JX: Distributions of glucocorticoid receptor gene polymorphisms in a Chinese Han population and associations with outcome after major trauma. Injury 40(5):479-483, 2009.

35. Sperry JL, Zolin S, Zuckerbraun BS, Vodovotz Y, Namas R, Neal MD, Ferrell RE, Rosengart MR, Peitzman AB, Billiar TR: $X$ chromosome-linked IRAK-1 polymorphism is a strong predictor of multiple organ failure and mortality postinjury. Annals of surgery 260(4):698-703; discussion 703-695, 2014.

36. Meyer NJ, Daye ZJ, Rushefski M, Aplenc R, Lanken PN, Shashaty MG, Christie JD, Feng R: SNPset analysis replicates acute lung injury genetic risk factors. BMC Med Genet 13:52, 2012.

37. Gu W, Zeng L, Zhou J, Jiang DP, Zhang L, Du DY, Hu P, Chen K, Liu Q, Wang ZG, et al.: Clinical relevance of 13 cytokine gene polymorphisms in Chinese major trauma patients. Intensive care medicine 36(7):1261-1265, 2010.

38. Schroeder O, Schulte KM, Schroeder J, Ekkernkamp A, Laun RA: The -1082 interleukin-10 polymorphism is associated with acute respiratory failure after major trauma: a prospective cohort study. Surgery 143(2):233-242, 2008.

39. Wen AQ, Gu W, Wang J, Feng K, Qin L, Ying C, Zhu PF, Wang ZG, Jiang JX: Clinical relevance of IL-1beta promoter polymorphisms $(-1470,-511$, and -31$)$ in patients with major trauma. Shock 33(6):576-582, 2010.

40. Hadjigeorgiou GM, Paterakis K, Dardiotis E, Dardioti M, Aggelakis K, Tasiou A, Xiromerisiou G, Komnos A, Zintzaras E, Scarmeas N, et al.: IL-1RN and IL-1B gene polymorphisms and cerebral hemorrhagic events after traumatic brain injury. Neurology 65(7):1077-1082, 2005.

41. Meyer NJ, Feng R, Li M, Zhao Y, Sheu CC, Tejera P, Gallop R, Bellamy S, Rushefski M, Lanken PN, et al.: IL1RN coding variant is associated with lower risk of acute respiratory distress syndrome and increased plasma IL-1 receptor antagonist. American journal of respiratory and critical care medicine 187(9):950-959, 2013.

42. Gu W, Zeng L, Zhang LY, Jiang DP, Du DY, Hu P, Wang HY, Liu Q, Huang SN, Jiang JX: Association of interleukin $4-589 T / C$ polymorphism with $T(H) 1$ and $T(H) 2$ bias and sepsis in Chinese major trauma patients. J Trauma 71(6):1583-1587, 2011.

43. Accardo Palumbo A, Forte GI, Pileri D, Vaccarino L, Conte F, D'Amelio L, Palmeri M, Triolo A, D'Arpa N, Scola L, et al.: Analysis of IL-6, IL-10 and IL-17 genetic polymorphisms as risk factors for sepsis development in burned patients. Burns : journal of the International Society for Burn Injuries 38(2):208-213, 2012.

44. Heesen M, Obertacke U, Schade FU, Bloemeke B, Majetschak M: The interleukin-6 G(-174)C polymorphism and the ex vivo interleukin- 6 response to endotoxin in severely injured blunt trauma patients. European cytokine network 13(1):72-77, 2002. 
45. Hildebrand F, Pape HC, van Griensven M, Meier S, Hasenkamp S, Krettek C, Stuhrmann M: Genetic predisposition for a compromised immune system after multiple trauma. Shock 24(6):518$522,2005$.

46. Gu W, Du DY, Huang J, Zhang LY, Liu Q, Zhu PF, Wang ZG, Jiang JX: Identification of interleukin6 promoter polymorphisms in the Chinese Han population and their functional significance. Crit Care Med 36(5):1437-1443, 2008.

47. Jeremic V, Alempijevic T, Mijatovic S, Sijacki A, Dragasevic S, Pavlovic S, Milicic B, Krstic S: Clinical relevance of IL-6 gene polymorphism in severely injured patients. Bosnian journal of basic medical sciences / Udruzenje basicnih mediciniskih znanosti = Association of Basic Medical Sciences 14(2):110-117, 2014.

48. Dalla Libera AL, Regner A, de Paoli J, Centenaro L, Martins TT, Simon D: IL-6 polymorphism associated with fatal outcome in patients with severe traumatic brain injury. Brain injury: [BI] 25(4):365-369, 2011.

49. Hildebrand F, Stuhrmann M, van Griensven M, Meier S, Hasenkamp S, Krettek C, Pape HC: Association of IL-8-251A/T polymorphism with incidence of Acute Respiratory Distress Syndrome (ARDS) and IL-8 synthesis after multiple trauma. Cytokine 37(3):192-199, 2007.

50. Huebinger RM, Rivera-Chavez F, Chang LY, Liu MM, Minei JP, Purdue GF, Hunt JL, Arnoldo BD, Barber RC: IL-10 polymorphism associated with decreased risk for mortality after burn injury. The Journal of surgical research 164(1):e141-145, 2010.

51. Schroder O, Laun RA, Held B, Ekkernkamp A, Schulte KM: Association of interleukin-10 promoter polymorphism with the incidence of multiple organ dysfunction following major trauma: results of a prospective pilot study. Shock 21(4):306-310, 2004.

52. Zeng L, Gu W, Chen K, Jiang D, Zhang L, Du D, Hu P, Liu Q, Huang S, Jiang J: Clinical relevance of the interleukin 10 promoter polymorphisms in Chinese Han patients with major trauma: genetic association studies. Critical care 13(6):R188, 2009.

53. Gong MN, Thompson BT, Williams PL, Zhou W, Wang MZ, Pothier L, Christiani DC: Interleukin10 polymorphism in position -1082 and acute respiratory distress syndrome. The European respiratory journal : official journal of the European Society for Clinical Respiratory Physiology 27(4):674-681, 2006.

54. Jin X, Hu Z, Kang Y, Liu C, Zhou Y, Wu X, Liu J, Zhong M, Luo C, Deng L, et al.: Association of IL10-1082 G/G genotype with lower mortality of acute respiratory distress syndrome in a Chinese population. Molecular biology reports 39(1):1-4, 2012.

55. Jeremic V, Alempijevic T, Mijatovic S, Arsenijevic V, Ladjevic N, Krstic S: Clinical relevance of IL10 gene polymorphism in patients with major trauma. Medicinski glasnik : official publication of the Medical Association of Zenica-Doboj Canton, Bosnia and Herzegovina 11(2):326-332, 2014. 
56. Stassen NA, Breit CM, Norfleet LA, Polk HC, Jr.: IL-18 promoter polymorphisms correlate with the development of post-injury sepsis. Surgery 134(2):351-356, 2003.

57. Zeng L, Zhang AQ, Gu W, Chen KH, Jiang DP, Zhang LY, Du DY, Hu P, Huang SN, Wang HY, et al.: Clinical relevance of single nucleotide polymorphisms of the high mobility group box 1 protein gene in patients with major trauma in southwest China. Surgery 151(3):427-436, 2012.

58. Duan ZX, Gu W, Zhang LY, Jiang DP, Zhou J, Du DY, Zen L, Chen KH, Liu Q, Jiang JX: Tumor necrosis factor alpha gene polymorphism is associated with the outcome of trauma patients in Chinese Han population. J Trauma 70(4):954-958, 2011.

59. Gill RM, Lee TH, Utter GH, Reed WF, Wen L, Chafets D, Busch MP: The TNF (-308A)

polymorphism is associated with microchimerism in transfused trauma patients. Blood 111(7):3880$3883,2008$.

60. Majetschak M, Obertacke U, Schade FU, Bardenheuer M, Voggenreiter G, Bloemeke B, Heesen M: Tumor necrosis factor gene polymorphisms, leukocyte function, and sepsis susceptibility in blunt trauma patients. Clinical and diagnostic laboratory immunology 9(6):1205-1211, 2002.

61. Menges T, Konig IR, Hossain H, Little S, Tchatalbachev S, Thierer F, Hackstein H, Franjkovic I, Colaris T, Martens F, et al.: Sepsis syndrome and death in trauma patients are associated with variation in the gene encoding tumor necrosis factor. Crit Care Med 36(5):1456-1462, e1451-1456, 2008.

62. O'Keefe GE, Hybki DL, Munford RS: The G-->A single nucleotide polymorphism at the -308 position in the tumor necrosis factor-alpha promoter increases the risk for severe sepsis after trauma. J Trauma 52(5):817-825; discussion 825-816, 2002.

63. Majetschak M, Flohe S, Obertacke U, Schroder J, Staubach K, Nast-Kolb D, Schade FU, Stuber F: Relation of a TNF gene polymorphism to severe sepsis in trauma patients. Annals of surgery 230(2):207-214, 1999.

64. Brochner AC, Toft P: Pathophysiology of the systemic inflammatory response after major accidental trauma. Scandinavian journal of trauma, resuscitation and emergency medicine 17:43, 2009.

65. Christie JD, Ma SF, Aplenc R, Li M, Lanken PN, Shah CV, Fuchs B, Albelda SM, Flores C, Garcia JG: Variation in the myosin light chain kinase gene is associated with development of acute lung injury after major trauma. Crit Care Med 36(10):2794-2800, 2008.

66. Rushefski M, Aplenc R, Meyer N, Li M, Feng R, Lanken PN, Gallop R, Bellamy S, Localio AR, Feinstein SI, et al.: Novel variants in the PRDX6 Gene and the risk of Acute Lung Injury following major trauma. BMC Med Genet 12:77, 2011. 
67. Schroder O, Schulte KM, Ostermann P, Roher HD, Ekkernkamp A, Laun RA: Heat shock protein 70 genotypes HSPA1B and HSPA1L influence cytokine concentrations and interfere with outcome after major injury. Crit Care Med 31(1):73-79, 2003.

68. Zhao Y, Tao L, Jiang D, Chen X, Li P, Ning Y, Xiong R, Liu P, Peng Y, Zhou YG: The -144C/A polymorphism in the promoter of HSP9Obeta is associated with multiple organ dysfunction scores. PLoS One 8(3):e58646, 2013.

69. Menges T, Hermans PW, Little SG, Langefeld T, Boning O, Engel J, Sluijter M, de Groot R, Hempelmann G: Plasminogen-activator-inhibitor-1 4G/5G promoter polymorphism and prognosis of severely injured patients. Lancet 357(9262):1096-1097, 2001.

70. Meyer NJ, Li M, Feng R, Bradfield J, Gallop R, Bellamy S, Fuchs BD, Lanken PN, Albelda SM, Rushefski M, et al.: ANGPT2 genetic variant is associated with trauma-associated acute lung injury and altered plasma angiopoietin-2 isoform ratio. American journal of respiratory and critical care medicine 183(10):1344-1353, 2011.

71. Canter JA, Norris PR, Moore JH, Jenkins JM, Morris JA: Specific polymorphic variation in the mitochondrial genome and increased in-hospital mortality after severe trauma. Annals of surgery 246(3):406-411; discussion 411-404, 2007.

72. Zhang AQ, Gu W, Zeng L, Zhang LY, Du DY, Zhang M, Hao J, Yue CL, Jiang J: Genetic Variants of microRNA Sequences and Susceptibility to Sepsis in Patients With Major Blunt Trauma. Annals of surgery 261(1):189-196, 2014. 